\title{
Analisis Perkembangan Manajemen Zakat untuk Pemberdayaan Masyarakat di Indonesia
}

\author{
Munif Solikhan \\ UIN Sunan Kalijaga Yogyakarta
}

Korespodensi dengan Penulis:

Munif Solikhan: Telp: 081804240756

E-mail: munifsolikhan@yahoo.com

\section{Keywords: Management, zakat, empowerment, Indonesia.}

\section{Kata kunci: \\ Manajemen, \\ zakat, \\ pemberdayaan, \\ Indonesia.}

\section{Abstract}

This study discusses the development of zakat management for community empowerment in Indonesia, this relates to the potential of zakat in Indonesia is large enough to reach trillions of rupiah. However, from zakat is not optimal by the wider community. This paper uses a qualitative descriptive analysis method with a literature review, which is by taking data from the results of research, the media, as well as the website of institutions and zakat stakeholders. From the results of the analysis found, history, zakat management has existed since Islam entered this country, through the colonial era, the era of independence, the new order period and then continued in the reformation period. The development of zakat management has been quite massive and the government has issued Law No. 38 of 1999 concerning zakat management. Amil Zakat Institutions began to appear and compete to issue programs to help find solutions to community problems. To overcome this problem, management divides into consumptive and productive alms. This second zakat has the same purpose which is to empower the community. In the consumptive zakat, the zakat fund is used to help the community directly, while in the productive zakat, the zakat fund is distributed by empowering the community supported by. From these results, the development of zakat management for community empowerment has progressed quite progressively but has not been able to optimally solve the problems in the community.

\section{Abstrak}

Kajian ini bertujuan menganalisis perkembangan manajemen zakat untuk pemberdayaan masyarakat di Indonesia. Hal ini didasarkan atas potensi zakat yang ada Indonesia bernilai cukup besar mencapai ratusan trilun rupiah. Akan tetapi dampak dari zakat belum dirasakan secara optimal oleh masyarakat luas. Tulisan ini menggunakan metode analisis deskriptif kualitatif dengan pendekatan kajian pustaka, yaitu dengan mengambil data dari hasil penelitian, media, serta website lembaga maupun stakeholder zakat. Dari hasil analisis tersebut ditemukan bahwa secara histori, manajemen zakat sudah ada sejak Islam masuk ke negeri ini, berlanjut ke zaman kolonial, zaman kemerdekaan, masa orde baru kemudian berlanjut di masa reformasi. Perkembangan manajemen zakat berjalan cukup masif ketika pemerintah menerbitkan UU No 38 tahun 1999 tentang manajemen 
zakat. Lembaga Amil Zakat mulai bermunculan dan berlomba mengeluarkan program untuk membantu mencari solusi permasalahan masyarakat. Untuk Mengatasi permasalahan tersebut manajemen zakat dibagi menjadi dua yakni zakat konsumtif dan zakat produktif. Kedua zakat ini memiliki tujan yang sama yaitu memberdayakan masyarakat. Di dalam zakat konsumtif dana zakat digunakan untuk membantu masyarakat yang bersifat langsung, Sedangkan di dalam zakat produktif, dana zakat didistrubusikan dengan cara memberdayakan masyarakat secara berkelanjutan. Dari hasil tersebut perkembangan manajemen zakat untuk pemberdayaan masyarakat berjalan cukup progresif meskipun belum bisa maksimal dalam menyelesaiakan permasalahan di masyarakat.

\section{PENDAHULUAN}

Zakat merupakan salah satu rukun Islam yang wajib dilaksanakan oleh umat Islam yang mampu atau sudah mencapai nisab dan haul. Selain itu perintah zakat di Al-quran sering kali disandingkan dengan perintah melaksanakan shalat. Shalat bisa diartikan sebagai hubungan antara manusia dengan tuhannnya (hablum min allah) sedangkan zakat diartikan sebagai hubungan manusia dengan manusia yang lainnya (Hablum min annas). Begitu sangat pentingnya zakat, ayat Al-quran menyebutkan kewajiban dalam membayar zakat sebanyak 30 kali. Seperti dalam salah satu firman Allah SWT dalam surat At-Taubah ayat 103 yang artinya: "ambillah zakat dari sebagian harta mereka, dengan zakat tersebut engkau membersihkan dan mensucikan mereka." Kewajiban dalam menunaikan zakat membuktikan bahwa Islam sangat memperhatikan permasalahan dan kesejahteraan di masyarakat. Selain itu Islam mengajarkan kepada ummatnya untuk selalu memiliki rasa kepedulian yang tinggi kepada saudaranya yang diwujudkan dengan menunaikan zakat.

Di Indonesia permasalahan zakat telah diatur dalam undang undang nomor 23 tahun 2011. Secara garis besar regulasi ini memberikan arahan yang jelas bagi proses manajemen zakat. Menurut undang-undang tersebut pengelolan zakat bertujuan: meningkatkan efektifitas dan efesiensi pelayanan dalam manajemen zakat, serta meningkatkan manfaat zakat dalam mewujudkan kesejahteraan masyarakat dan penanggulangan kemiskinan. Agama dan negara telah memberikan arahan yang jelas terhadap proses pelaksanaan zakat. Agama memberikan perintah dalam bentuk wujud manifestasi keimanannya, sedangkan negara memberikan payung hukum atau regulasi yang jelas guna melindungi umat agar “aman dan nyaman" dalam menjalankan keyakinannya.

Indonesia merupakan negara dengan populasi muslim terbesar di dunia, Berdasarkan data yang dilansir oleh The Pew Forum on Religion and Public Life, penganut agama Islam di Indonesia sebesar 209,1 juta jiwa atau 87,2 persen dari total penduduk. Jumlah itu 
merupakan 13,1 persen dari seluruh umat muslim di dunia. ${ }^{1}$ Setelah melihat jumlah penduduk muslim di atas, tentu zakat memiliki potensi yang cukup besar untuk dikembangkan. Potensi zakat Indonesia dalam setahun mencapai Rp 217 triliun. Angka potensial ini muncul dalam riset berjudul Economic Estimation and Determinations of Zakat Potential in Indonesia oleh Institut Pertanian Bogor (IPB), Badan Amil Zakat Nasional (Baznas), dan Islamic Development Bank (IDB) tahun 2011.²

Berdasarkan hasil riset yang telah dikeluarkan diatas zakat di Indonesia memiliki potensi yang sangat besar, Angka yang terdapat diatas seharusnya bisa berdampak besar dalam upaya untuk kesejahteraan masyarakat di Indonesia. Akan tetapi Menurut laporan BAZNAS menyatakan bahwa dari potensi zakat tersebut hanya bisa terserap dan dikelola oleh lembaga BAZNAS baru mencapai Rp. 450 Milyar untuk tahun 2007, meningkat menjadi Rp 2,73 triliun pada tahun 2013 atau hanya sekitar 1\% saja. ${ }^{3}$ Meskipun dalam amanat undang undang diperbolehkan lembaga non structural pemerintah untuk mengelola zakat. Ada terdapat puluhan lembaga yang terdaftar di pemerintah sebagai lembaga pengelola zakat.

Melihat potensi yang begitu besar baik dari sisi materi ataupun jumlah penduduk, zakat di negara ini seharusnya bisa memberikan dampak yang cukup signifikan terhadap kesejahteraan dan pemberdayaan ekonomi umat. Akan tetapi yang terjadi dilapangan kemiskinan masih menjadi permasalahan klasik yang belum terselesaikan di negeri ini. meskipun pemerintah Indonesia mengklaim telah berhasil angka kemiskinan menjadi satu digit, tetapi kemiskinan masih diangka puluhan juta. Selama ini bantuan yang diberikan oleh lembaga filantropi masih banyak berkutat pada bantuan pemberian konsumftif belum pada tataran pemberdayaan umat, seperti bantuan langsung ekonomi, kesehatan, serta jasa langsung lainnya. Hal ini akan menyebabkan pemberdayaan ekonomi umat tidak bisa berkembang dengan baik.

Dalam istilah Pemberdayaan ekonomi masyarakat, zakat merupakan suatu tindakan pemindahan harta dari golongan yang kaya kepada golongan miskin. Oleh karena itu pelarangan riba dan perintah membayar zakat (Q.S al-Baqarah/2:276) adalah dua konsep yang selalu dikemukakan setiap pembahasan yang berhubungan dengan sosial ekonomi Islam. ${ }^{4}$ Perlu digaris bawahi bahwa zakat bukan hanya sekadar bagian dari rukun Islam

1 Kata Data, Indonesia Negara Berpenduduk Muslim Terbesar Dunia, https://databoks.katadata.co.id/datapublish/2016/11/11/Indonesia-negara-berpenduduk-muslimterbesar-dunia, akses pada 15 Agustus 2019.

2 Dompet Dhuafa, Optimalisasi Potensi Zakat di Indonesia,
http://www.dompetdhuafa.org/post/detail/7626/optimalisasi-potensi-zakat-Indonesia. akses 15 Agustus 2019

3 Clarashinta Canggih, Khusnul Fikriyah, dan Ach. Yasin, "Potensi dan Realisasi Dana Zakat Indonesia", Jurnal al-udud, Vol.1, No 1, 2017. hlm 15.

4 Amalia dan Kasyful Mahalli, "Potensi dan Peranan Zakat dalam Mengentaskan Kemiskinan di Kota Medan", Jurnal Ekonomi dan Keuangan, Vol. 1, No.1, 2012. hlm 72. 
yang menjadi suatu kewajiban seorang muslim, namun jika dipahami dari segi konsep filosofis bahwa zakat mampu mensejahterakan masyarakat secara umum, karena dengan berzakat akan menciptakan suasana yang harmonis dan mempunyai rasa sikap saling peduli terhadap sesama yang lebih membutuhkan. ${ }^{5}$

Guna mengoptimalkan potensi zakat yang cukup besar, di Indonesia secara undang undang telah diatur tentang siapa yang mengelola zakat, baik itu zakat mal maupun zakat fitrah. Pada tataran pemerintah kita biasa mengenal BAZNAS (Badan Amil Zakat Nasional), dan di tataran non pemerintah terdapat lembaga lembaga seperti LAZISNU, LAZISMU, IZI, Rumah Zakat Indonesia, serta OPZ organisasi pengelola zakat lainnya yang berada dibawah institusi institusi tertentu. Bahkan pada tataran zakat fitrah hampir di masjid di seluruh wilayah Indonesia mengelola zakat.

Kajian mengenai perkembangan manajemen zakat di Indonesia sudah ada beberapa yang telah dilakukan, yang pertama adalah dari Zusiana Elly Triantini, dengan judul Perkembangan Manajemen Zakat Di Indonesia, tulisan ini banyak membahas tentang formalisasi pengelolaan zakat di Indonesia mengkaji tentang perkembangan zakat di Indonesia, terutama rentetan sejarah politik pengelolaan dan pendayagunaan zakat di Indonesia dari masa ke masa. ${ }^{6}$ Kajian selanjutnya dikemukakan oleh Ahmad Attabik dengan judul manajemen pengelolaan zakat yang efektif di era kontemporer. Tulisan ini banyak membahas terkait dengan masalah nisob, zakat profesi, pengelolaan zakat untuk kesejaheraan umat Islam dan mengelola zakat dengan menggunakan teori manejemen James Stoner.7

Melihat berbagai permasalahan dan berbagai kajian di atas penulis ingin menganalisis bagaimana perkembangan manajemen Zakat untuk pemberdayaan masyarakat di Indonesia, hal ini dengan didasarkan kepada potensi dan banyaknya lembaga zakat yeng telah ada, apakah hal tersebut mempunyai dampak yang cukup signifikan terhadap pemberdayaan masyarakat di Indonesia. Selain itu apakah zakat telah dikelola sesuai dengan cita-cita umat Islam yang mampu menjadikan umatnya terlepas dari belenggu kemiskinan untuk menuju umat yang sejahtera. Tulisan ini menganalisis secara komprehensif untuk melihat sampai sejauh mana zakat di Indonesia bisa bermanfaat bagi pemberdayaan masyarakat.

${ }^{5}$ Didin Hafidhuddin, Zakat dalam Perekonomian modern, (Jakarta: Gema Insani, 2002), hlm. 66.

${ }^{6}$ Zusiana Elly Triantini, "Perkembangan Manajemen Zakat Di Indonesia", Jurnal Al - Ahwal, Vol. 3, No. 1, 2010, hlm 87.

7 Ahmad Atabik, "Manajemen Pengelolaan Zakat Yang Efektif Di Era Kontemporer" Jurnal Ziswaf, Vol. 2, No. 1, 2015, hlm 59. 


\section{PEMBAHASAN}

\section{Perkembangan Manajemen Zakat di Indonesia}

Perkembangan manajemen zakat di Indonesia secara massif dilakukan berbarengan dengan masuknya Islam di Indonesia, dalam catatan sejarah Islam masuk dimulai dari Aceh Pada masa Kerajaan Islam Aceh, misalnya, masyarakat menyerahkan zakat-zakat mereka kepada negara yang mewajibkan zakat/pajak kepada setiap warga negaranya. ${ }^{8}$ Pemerintah kerajaan pada waktu itu berperan aktif untuk mengambil zakat langsung kepada muzakki, karena menurut sebagian ulama berpendapat bahwa yang wajib memungut zakat adalah pemerintah sah yang sedang berkuasa. Kantor pembayaran pajak ini pada masa kekuasaan kerajaan Aceh berlangsung di masjid-masjid. Seorang imeum dan kadi (penghulu) ditunjuk untuk memimpin penyelenggaraan ritual-ritual keagamaan. Penghulu berperan besar dalam mengelola keuangan masjid yang bersumber melalui zakat, sedekah, hibah, maupun wakaf. 9

Pada masa pemerintahan kolonialisme Belanda, zakat digunakan sebagai sumber keuangan bagi perjuangan rakyat Indonesia untuk melawan penjajah. Hal ini diketahui oleh pemerintah kolonial untuk segera menutup sumber dana tersebut, yaitu dengan cara melarang para masyarakat pribumi untuk tidak membayar zakat. Dengan berlakunya pelarangan tersebut pelaksanaan zakat di tanah air menjadi tersendat dan tidak bisa mekasimal. Namun kemudian, pada awal abad XX, diterbitkanlah peraturan yang tercantum dalam Ordonantie Pemerintah Hindia Belanda Nomor 6200 tanggal 28 Pebruari 1905. Dalam peraturan tersebut Pemerintah Belanda tidak lagi mencampuri urusan manajemen zakat, dan sepenuhnya manajemen zakat diserahkan kepada umat Islam. ${ }^{10}$

Setelah Indonesia mendapatkan kemerdekaannya zakat kembali mendapatkan perhatian yang cukup besar dari para fuqoha yang ada di negeri ini. Oleh karena itu dalam UUD 45 pada pasal 29 dan pasal 34 yang menjelaskan kebebasan menjalankan keyakinannya dan fakir miskin serta anak terlantar dipelihara oleh negara. Melihat dari beberapa kata di dalam UUD 45 tersebut yaitu kebebasan berkeyakinan/beragama dan fakir miskin dan anak terlantar zakat mempunyai tempat yang cukup strategis dalam undang undang dasar. Zakat bisa berperan aktif dalam hal memberdayakan rakyat miskin dan anak terlantar sebagai mustahiq. Selanjutnya hal tersebut ditindaklanjuti dengan Kementerian Agama mengeluarkan Surat Edaran Nomor: A/VII/17367, tanggal 8 Desember 1951 tentang Pelaksanaan Zakat Fitrah. Kementerian Agama melakukan pengawasan supaya pemakaian

${ }^{8}$ C. van Vollenhoven, Het Adatrecht van Nederlandsch Indie, Jilid. I, (Leiden: E.J. Brill, 1931), hlm 164.

${ }^{9}$ Azyumardi Azra, Filantropi dalam Sejarah Islam di Indonesia, (Jakarta: Forum Zakat (FOZ), 2006)), hlm 20.

10Faisal, "Sejarah Manajemen Zakat Di Dunia Muslim Dan Indonesia (Pendekatan Teori Investigasi-Sejarah Charles Peirce dan Defisit Kebenaran Lieven Boeve", Jurnal Analisis, Vol. XI, No. 2, 2011. hlm 259. 
dan pembagian hasil pungutan zakat berlangsung menurut hukum agama. ${ }^{11}$ Pada masa pemerintahan orde lama perumusan terkait zakat terjadi dinamika yang cukup pelik, terjadi tarik menarik antara kementerian agama dengan kementerian keuangan dan akhirnya muncul intruksi menteri agama untuk menunda undang-undang manajemen zakat.

Pada masa pemerintahan Soeharto manajemen zakat sedikit mendapatkan tempat untuk berkembang, hal ini ditunjukkan dengan pendirian BAZIS (Badan Amil Zakat Infak Shodaqoh) pada tanggal 22 oktober 1968 yaitu diawali dengan pendirian BAZIS di Jakarta dan diikuti oleh daerah-daerah yang lain di Indonesia. Pemerintah Indonesia melalui Departemen Agama pada tahun 1984 mengeluarkan Instruksi Menteri Agama Nomor 2 tahun 1984 tanggal 3 Maret 1984 tentang Infaq Seribu Rupiah selama bulan Ramadhan yang pelaksanaannya diatur dalam Keputusan Direktur Jendral Bimas Islam dan Urusan Haji Nomor 19/1984 tanggal 30 April 1984. Pada tanggal 12 Desember 1989 dikeluarkan Instruksi Menteri Agama 16/1989 tentang Pembinaan Zakat, Infaq, dan Shadaqah yang menugaskan semua jajaran Departemen Agama untuk membantu lembaga-lembaga keagamaan yang mengadakan manajemen zakat, infaq, dan shadaqah agar menggunakan dana zakat untuk kegiatan pendidikan Islam dan lainnya. Selanjutnya Pada tahun 1991 pemerintah mengeluarkan Keputusan bersama Menteri Agama dan Menteri Dalam Negeri Nomor 29 dan 47 tahun 1991 tentang Pembinaan Badan Amil Zakat, Infaq, dan Shadaqah yang selanjutnya dilanjutkan dengan Instruksi Menteri Agama Nomor 5 tahun 1991 tentang Pedoman Pembinaan Teknis Badan Amil Zakat, Infaq, dan Shadaqah dan Instruksi Menteri Dalam Negeri Nomor 7 tahun 1988 tentang Pembinaan Umum Badan Amil Zakat, Infaq, dan Shadaqah. 12

Seiring dengan perkembangan zaman manajemen zakat di Indonesia terus mengalami perkembangan yang cukup pesat, pada masa reformasi manajemen zakat cukup mendapat tempat yang baik sering adanya perbaikan dan perubahan besar-besaran di negeri ini. manajemen zakat kembali disempurnakan untuk menjadi lebih baik demi kesejahteraan umat, Hal ini ditunjukkan dengan dikeluarkannya UU no 38 tahun 1999 tentang manajemen zakat. Selanjutnya diikuti dengan dikeluarkannya Keputusan Menteri Agama nomor 581 tahun 1999 tentang Pelaksanaan Undang-undang Nomor 38 tahun 1999 dan Keputusan Direktur Jendral Bimas Islam dan Urusan Haji Nomor D-291 tahun 2000 tentang Pedoman Teknis Manajemen Zakat.13 Perubahan UU diatas ditujukan untuk membuat masyarakat bisa berdaya dan mandiri secara ekonomi yang nantinya akan bermuara kepada kesejahteraan bersama. Aturan yang dibuat berfungsi sebagai payung hukum untuk

11 Depag RI, Pedoman Zakat, (Jakarta: Badan Proyek Peningkatan Zakat dan Wakaf, 2002), hlm 284.

12 Fakhruddin, Fiqh dan Manajemen Zakat di Indonesia, (Malang: UIN Malang Press, 2008), hlm 246.

${ }^{13}$ Fakhruddin, Fiqh dan Manajemen ... hlm 247. 
melindungi sekaligus memberi arahan yang jelas bagi manajemen zakat, yang nantinya zakat bisa mengatasi permasalahan kemiskinan dan kesejahteraan di tengah masyarakat.

Undang undang No 38 tahun 1999 tentang manajemen zakat mengakibatkan masyarakat menjadi antusias untuk mengelola dan mengembangkan zakat menjadi lebih baik, selama ini masyarakat hanya mengelola zakat fitrah di masjid-masjid di bulan Ramadhan, selanjutnya mereka mengembangkan manajemen zakat dengan mendirikan lembaga amil zakat (LAZ) mandiri seperti di institusi institusi mereka sendiri atau mendirikan dan mengelola zakat secara professional. Hal ini ditunjukkan dengan banyaknya lembaga lembaga amil swasta yang muncul di masyarakat. Muncul Lembaga Amil Zakat (LAZ) yang disahkan, yakni (1) Dompet Dhuafa, (2) Yayasan Amanah Takaful, (3) Pos Keadilan Peduli Ummat (PKPU), (4) Yayasan Baitul Maal Muamalat, (5) Yayasan Dana Sosial Al Falah, (6) Yayasan Baitul Maal Hidayatullah, (7) LAZ Persatuan Islam (PERSIS), (8) Yayasan Baitul Maal Ummat Islam (BAMUIS) PT BNI (persero) tbk, (9) LAZ Yayasan Bangun Sejahtera Mitra Umat, (10) LAZ Dewan Dakwah Islamiyah Indonesia, (11) LAZ Yayasan Baitul Maal Bank Rakyat Indonesia, (12) LAZIS Muhammadiyah, (13) LAZ Baitul Maal Wat Tamwil (BMT), (14) LAZ Yayasan Dompet Sosial Ummul Quro (DSUQ), (15) LAZ Baituzzakah Pertamina (BAZMA), (16) LAZ Dompet Peduli Ummat Daarut Tauhid (DPUDT), (17) LAZ Nahdlatul Ulama (NU), dan (18) LAZ Ikatan Persaudaraan Haji (IPHI) dan masih banyak lagi yang lainnya. ${ }^{14}$

\section{Manajemen Zakat Untuk Pemberdayaan Masyarakat}

Melihat perkembangan manajemen zakat di Indonesia di atas, secara histori sudah berjalan cukup panjang dari zaman masuknya Islam sampai pada saat ini. pada saat ini lembaga pengelola zakat semakin banyak bermunculan seiring dengan semangatnya masyarakat untuk menerapkan nilai nilai Islam dalam dirinya, akan tetapi apakah hal tersebut bisa menjadi solusi atas permasalahan ekonomi umat Islam saat ini? Pengelola zakat (Amil Zakat) memiliki peran yang sangat penting dalam umat. Sesuai dengan hal itu, pengelola zakat memiliki tanggung jawab kepada orang yang terkait dengan kegaiatn zakat. Para pengelola zakat dalam Pasal 8 UU Nomor 38 Tahun 1999 menyebutkan bahwa Amil Zakat mempunyai tugas pokok yaitu mengumpulkan, mendistribusikan zakat sesuai dengan ketentuan agama. Sesuai dengan UU di atas maka Amil Zakat memiliki tugas sebagai berikut: (1) Fungsi penghimpun zakat. (2) Fungsi pendistribusian Zakat. (3) Tugastugas yang lain merupakan turunan dari tugas utama yang ada di atas, seperti pencatatan, pemeliharaan dan manajemen.

Manajemen zakat memerlukan persiapan dan perencanaan yang tepat dan terarah. Semua kegiatan dan aspek yang terkait dengan kegaiatan tersebut harus terencana, terorganisir, terkontrol serta adanya evaluasi sampai di mana capaian kinerjanya. Hal

\footnotetext{
${ }^{14}$ Zusiana Elly Triantini, “Perkembangan Manajemen ...hlm 94.
} 
tersebut perlu dilakukan supaya manajemen zakat bisa dilaksanakan secara efektif dan efisien. Tujuan zakat dapat dikatakan tercapai ketika zakat dikelola dengan baik yang sesuai dengan prinsip-prinsip yang ada dalam manajemen. Maksudnya disini adalah, manajemen zakat sebagai perantara untuk kesempurnaan pelaksanaan zakat. Oleh sebab itu, dalam menghimpun zakat mestinya didasarkan pada prinsip-prinsip manajemen. ${ }^{15}$ Menurut Para ulama' terdapat berbagai pendapat tentang manajemen dalam tata kelola zakat, meskipun demikian proses dalam mengumpulkan zakat yang berbasis dengan prinsip prinsip manajemen adalah suatu keniscayaan dalam masyarakat saat ini.

Kemampuan lembaga pengelola zakat akan tergantung pada kredibilitasnya dalam mengelola zakat secara tanggung jawab, transparan, professional, serta adil dan tetap sasaran. Mengapa demikian dikarenakan saat ini pada umumnya para muzakki lebih senang mengeluarkan zakat secara langsung kepada para penerima zakat. Meskipun muncul beberapa lembaga amil zakat masyarakat dalam melakukan Pembayaran zakat dilakukan secara sendiri-sendiri mengikuti tradisi yang sudah ada dari orang terdahulu, tanpa didasari pemahaman yang menyeluruh (kaffah), sehingga masih belum dikelola secara profesional terencana dan terorganisir pemanfaatan serta disribusi yang belum merata, dan juga belum bisa optimasi pemberdayaan potensi zakat untuk mengentaskan kemiskinan. ${ }^{16} \mathrm{Hal}$ tersebut bisa dibuktikan dengan adannya fenomena ketika bulan puasa (Ramadhan) menjelang hari raya banyak masyarakat yang tergolong mampu membagikan zakatnya dengan langsung membagikan kepada ummat, yang mengakibatkan kericuhan dan bahkan menimbulkan korban jiwa. Oleh karena itu diperlukan edukasi, sosialisasi dan memahamkan kepada masyarakat untuk membayar zakat melalui lembaga amil yang professional.

Meskipun belum maksimalnya manajemen zakat yang ada di Indonesia jika dibandingkan dengan potensi yang telah ada, akan tetapi dengan adanya peraturan dari pemerintah ataupun UU yang menaunginya banyak muncul lembaga zakat yang aktif dalam hal dari pengumpulan maupun distribusi zakat bahkan sampai pada tataran pemberdayaan ekonomi ummat. Untuk memberdayakan ekonomi masyarakat melalui zakat penulis membagi menjadi dua yaitu, zakat konsumtif dan zakat produktif.

\section{Zakat Konsumtif}

Menurut penulis zakat konsumtif merupakan salah satu pemberdayaan ekonomi umat yang bersifat sementara dan mendesak, yang selanjutnya bisa dikembangkan menjadi pemberdayaan ekonomi ummat. Saat ini ada beberapa bentuk manajemen dana zakat yang dapat dilakukan melalui beberapa cara, yaitu bantuan biaya hidup (santunan), bantuan

15 Hasan Muhammad, "Manajemen Zakat: Model Manajemen Zakat yang Efektif", (Yogyakarta: Penerbit Idea Press, 2011). hlm 17.

${ }^{16}$ Hasan Muhammad, Manajemen.... hlm 18. 
biaya pendidikan, bantuan kesehatan, desa berbasis kemitraan (desa binaan) dan beberapa bantuan yang lain. ${ }^{17}$

1) Bantuan Biaya hidup (santunan)

Manajemen dana zakat untuk kebutuhan biaya hidup, merupakan manajemen zakat yang paling banyak dilakukan di hampir semua lembaga amil zakat. Misalnya dengan memberikan uang tunai langsung, makanan ataupun sembako, memberikan pakaian, yang pada intinya membantu kebutuhan dasar kepada fakir miskin yang membutuhkan. Proses manajemen maupun distribusinya bisa dilakukan dengan cara yang bermacam macam misalnya melakukan koordinasi dengan lingkungan ataupun pemerintah setempat untuk mendata dan kemudian menyerahkannya. Seperti yang terjadi di salah satu daerah di provinsi Jambi, Kota Sungai Penuh Sebanyak 278 mustahik menerima bantuan biaya hidup yang diserahkan langsung oleh Walikota H. Asafri Jaya Bakri (AJB), Rabu (24/4/2019). Bantuan biaya hidup tersebut dibagikan kepada warga kurang mampu itu berasal dari zakat para ASN di lingkungan pemerintah kota Sungai Penuh yang dikumpulkan Badan Amil Zakat daerah (BAZDA). ${ }^{18}$ Selain itu juga para amil zakat di lembaga amil zakat langsung mendata, mendatangi dan sekaligus menyerahkan bantuan kepada para mustahik yang membutuhkan. Akan tetapi ada beberapa fenomena yang terjadi di beberapa daerah di Indonesia para muzakki menyerahkan zakatnya kepada pemuka agama, selanjutnya sang pemuka agama tersebut membagikan zakat sang muzakki kepada fakir miskin. Disamping dengan cara di atas ada beberpa muzakki menyerahkan langsung kepada mustahik dengan membagikan uang tunai padna saat bulan Ramadhan menjelang hari raya idul fitri. Hal ini pernah menjadi berita yang kurang mengenakkan pada tahun 2008 tepatnya di pasuruan, peristiwa pembagian zakat yang dilakukan keluarga seorang dermawan, H. Syaichon di Jl. Dr. Wahidin Sudirohusodo Kota Pasuruan, Jawa Timur, Senin (15/9/2008), terus bertambah, tercatat 21 orang meninggal dunia. ${ }^{19}$ mereka berdesak desakkan dan akhirnya terinjak-injak hanya untuk mengambil uang zakat dari sang muzakki sebesar Rp 30.000.20

2) Zakat untuk Pendidikan

Pada zaman Rasulullah biaya untuk pendidikan tidak masuk dalam kegiatan zakat, akan tetapi pada saat ini banyak lembaga amil zakat memanfaatkan zakat untuk bantuan biaya pendidikan. Zakat untuk pendidikan adalah zakat yang diperuntukkan kepada oarang yang sedang menempuh pendidikan dari golongan masyarakat tidak mampu.

${ }^{17}$ Mubasirun, "Distribusi Zakat Dan Pemberdayaan Ekonomi Umat", Jurnal inferensi, Vol. 7, No. 2, 2013. hlm 500 .

18 Jambi link, Bantuan Biaya Hidup Bagi Warga Kurang Mampu Dari Zakat PNS, https://jambilink.com/2019/04/24/bantuan-biaya-hidup-bagi-warga-kurang-mampu-dari-zakatpns/amp, Akses 20 Januari 2020.

Repubika, 21 Korban Tewas Pembagian Zakat di Pasuruan, https://www.republika.co.id/berita/breaking-news/nasional/08/09/15/3018-21-korban-tewaspembagian-zakat-di-pasuruan, Akses, 20 Januari 2020. 
Dilihat dari sudut pandang penetapan penilaian bagi penerima zakat dapat disambungkan dengan pendistribusian zakat untuk tujuan pendidikan bisa dikaitkan dengan asnaf fi sabilillah, asnaf fakir miskin, mualaf dan ibnu sabil. ${ }^{21}$ terdapat beberapa perbedaan dikalangan ulama terkait zakat untuk kegiatan pendidikan ada yang setuju dengan pendapat di atas ada juga yang menentangnya. Kita kesampingkan permasalahan khilafiyah tersebut dengan memilih bolehnya zakat untuk pendidikan. Zakat pendidikan bisa digologkan menjadi zakat konsumtif karena pemberiannya diberikan secara langsung kepada asnaf untuk kegiatan bantuan pendidikan. Misalnya hoshigora.org, membuat kegiatan program Zakat Hoshizora, pelajar di Indonesia yang kurang mampu secara keuangan diberikan bantuan beasiswa pendidikan dan pendampingan untuk mewujudkan impian mereka. Jumlah beasiswa yang diterima setiap bulan berkisar: SD 100 ribu, SMP 150 ribu, SMA 200 ribu. Selain itu bantuan tersebut berupa berupa barang-barang peralatan sekolah seperti: seragam sekolah, buku, perlengkapan sekolah lainnya, dan alat pendukung lainnya. 22 zakat untuk biaya pendidikan ada yang berpendapat sebagai zakat produktif karena berdampak jangka panjang. Akan tetapi penulis berpendapat sebagai zakat konsumtif, karena dana yang diberikan langsung berupa bentuk barang dan uang untuk membayar SPP. Sistem penyalurannya bisa berupa, lembaga amil menyerahkan langsung ke mustahik atau lembaga amil zakat bekerjasama dengan pemerintah setempat.

3) Zakat untuk kesehatan

Penggunaan zakat untuk kesehatan bisa digolongkan ke asnaf fakir dan miskin. Oleh karena itu ada beberapa lembaga amil zakat menyalurkan dananya untuk membantu fakir miskin untuk menyembuhkan sakitnya. Misalnya yang terjadi di Yogyakarta, Baznas Yogyakarta mendirikan rumah sehat BAZNAS. Rumah Sehat BAZNAS merupakan program pelayanan kesehatan secara cuma cuma untuk rakyat miskin, rumah sehat ini sering juga disebut sebagai Rumah Sakit tanpa kasir, sebab tidak ada loket kasir pembayaran.23 Pelayanan kesehatan yang lakukan oleh rumah sehat ini sudah sesuai dengan standar kesehatan rumah sakit pada umumnya yaitu berbentuk pelayanan dalam gedung dan di luar gedung. Pelayanan yang ada dalam gedung terdiri dari pelayanan poli Umum, instalasi Gawat Darurat, poli mulut dan gigi, Unit obat obatan, Laboratorium, Poli Gizi, Sahabat senyum (kilnik Psikologi) dan Ambulance. ${ }^{24}$ Selain itu menurut Bambang Sudibyo (sekretaris jendral world zakat forum) Zakat bisa digunakan untuk menutup defisit

21 Zakaria Bahari, "Peran Zakat dalam Pendidikan Masyarakat Islam: Ulasan Kasus Zakat Pulau Pinang", Jurnal Media Syariah, Vol. XVI No. 1, Juni 2014, hlm 180.

22 Hishora Fondation, Zakat Pendidikan Untuk Anak Indonesia, https://www.hoshizora.org/zakat-untuk-pendidikan-anak-Indonesia/, Akses 21 Januari 2020.

${ }^{23}$ Iskandar Zulkarnain, "Manajemen Dana Zakat Bagi Pelayanan Kesehatan Mustahik (Studi Pada Rumah Sehat Baznas Yogyakarta)", Skripsi, (Yogyakarta: Universitas Islam Indonesia, 2018), hlm 38.

24 Iskandar Zulkarnain, Manajemen...hlm. 38. 
BPJS, dan juga membantu iuran BPJS untuk kalangan fakir miskin. ${ }^{25}$ Di samping adanya rumah sakit dan bantuan kesehatan kepada fakir miskin banyak lembaga lembaga amil zakat di negeri ini menyediakan ambulan yang bisa digunakan masyarakat secara gratis. manajemen zakat untuk kegiatan kesehatan sangat terasa manfaatnya terutama bagi masyarakat miskin yang sebelumnya tidak mampu menjangkau akses dalam mendapatkan kesehatan.

Saat ini zakat konsumtif masih diperlukan untuk pemberdayaan ekonomi masyarakat. Sebelum kaum dhuafa mandiri secara ekonomi, penting untuk dipenuhi kebutuhan dasarnya terlebih dahulu. Hal ini dikarenakan perintah agama untuk mendahulukan kebutuhan dasar masyarakat kurang mampu. Setelah terpenuhi kebutuhan dasarnya dilanjutkan dengan pemberdayaan ekomomi jangka panjang dengan pendampingan.

\section{Zakat Produktif}

Zakat produktif didefinisikan sebagai pemberian zakat, yang nantinya bisa membuat mustahik mendapatkan hasil secara berkelanjutan dengan dana zakat yang telah diterimanya. Zakat produktif bisa artikan sebagai zakat dimana harta atau dana zakat yang diserahkan kepada para asnaf atau mustahik tidak konsumsi langsung dan habis, akan tetapi dikembangkan dan berdayakan guna membantu kegaiatan usaha mereka, hal ini bertujuan mereka bisa memenuhi kebutuhan hidup secara terus menerus tanpa mengandalkan bantuan secara tunai. ${ }^{26}$

Guna membebaskan dari belenggu kemiskinan dan ketergantungan mereka terhadap bantuan orang lain, diperlukan pemberdayaan zakat yang produktif. Sidang Bahtsul Masail Diniyah Maudhuiyyah (pembahasan masalah masalah penting tentang agama) pada saat Muktamar NU ke-28, memberikan rekomendasi bahwa ada dua hal di atas diperbolehkan dengan tujuan guna meningkatkan taraf ekonomi mustahiq zakat. Akan tetapi ada syarat penting bahwa calon penerima zakat itu sendiri sebelumnya harus mengetahui bahwa harta zakat harus mengetahui bahwa harta yang diterimanya tersebut dikembangkan secara produktif. ${ }^{27}$

Penyaluran zakat produktif bisa dilakukan dalam bentuk seperti: Pertama, sistem in kind, yaitu dana zakat diserahkan dalam bentuk mesin-mesin produksi yang diperlukan oleh sang penerima zakat yang akan berproduksi, baik mereka yang baru mulai usahanya ataupun yang sudah berusaha untuk pengembangan usaha untuk yang lebih baik. Kedua

25 Media Indonesia, Zakat Bisa Dimanfaatkan Warga Miskin Bayar BPJS Kesehatan, https://mediaIndonesia.com/read/detail/269661-zakat-bisa-dimanfaatkan-warga-miskin-bayarbpjs-kesehatan, pada tanggal 22 Januari 2020

${ }^{26}$ Asnainu, Zakat Produktif dalam Persfektif Hukum Islam, (Yogyakarta: Pustaka Pelajar, 2008), hlm 64.

27 Anonim, Hukum Zakat Produktif untuk Pendayagunaan Mustahik, https://Islam.nu.or.id/post/read/46324/hukum-zakat-produktif-untuk-pendayagunaan-mustahik Akses 22 Januari 2020.

${ }^{27}$ Mubasirun, Distribusi Zakat...hlm 501. 
adalah dengan sistem Qordul Hasan yakni lembaga amil zakat memberikan modal kepada mustahik dan nantinya hanya mengembalikan dana tersebut pinjaman pokoknya tanpa ada bagi hasil. Ketiga dengan sistem mudhorobah adalah lembaga amil zakat modal kepada penerima zakat tetapi mengembalikan dengan konsekuensi mengembalikan pinjaman bagi hasil. 28

Dari pembagian macam-macam zakat di atas diharapkan arah manajemen zakat produktif menjadi lebih jelas, dan mencapai sasaran yang telah dituju. Pola pengembangan zakat dengan model di atas dirasakan lebih besar manfaatnya dibandingkan dengan manajemen zakat konsumtif, hal ini dikarenakan menciptakan kemandirian umat yang nantinya akan bermuara kepada kesejahteraan masyarakat, berikut ini akan dijelaskan beberapa program kegiatan yang dilaksanakan lembaga amil zakat, dalam rangka memberdayakan masyarakat di Indonesia.

1) Pemberdayaan ekonomi masyarakat

Manajemen dana zakat untuk Pemberdayaan ekonomi harus paling utama dilakukan demi tujuan kesejahteraan mayarakat, saat ini di beberapa lembaga zakat sudah mengembangkan program ekonomi umat, misalnya di Dompet Dhuafa memiliki 4 program pengentasan kemiskinan yaitu: pertama program masyarakat mandiri (MM), Program ini diberikan bertujuan memutus lingkaran kemiskinan di wilayah wilayah yang telah dipetakan. Program ini bisa mencapai kepada perkumpulanperkumpulan di pedesaan, perkotaan, wilayah sesudah bencana, dan masyarakat berdasarkan tingkatan ekonomi. Kedua program kampoeng ternak nusantara, program ini meliputi program pembibitan, pakan, manajemen, teknologi, dan veteriner. Ketiga program pertanian sehat Indonesia yaitu program pengembangan dan penelitian produk pertanian, pembasmian hama, dan pupuk. ${ }^{29}$

Lembaga amil zakat lain yaitu Rumah Zakat Indonesia (RZI) memilki program zakat produktif yaitu: senyum mandiri yaitu program tentang kewirausahaan, program janda berdaya yaitu dengan memberdayakan janda janda miskin untuk bisa hidup mandiri. Lembaga amil zakat milik pemerintah juga memiliki beberapa program pemberdayaan ekonomi masyarakat yaitu: progam "lumbung pangan" program ini bergerak dalam bidang sektor peternakan dan pertanian, para mustahik diberikan fasilitas produksi pertanian, teknologi pertanian, lahan, dan akses pemasaran, program selanjutnya adalah "mustahik pengusaha" yaitu memberdayakan para mustahik agar mampu berwirausaha mikro dan mampu menjalankan usahanya dengan pendampingan. Kemudian selanjutnya ada program "Z-Mart" yaitu program retail yang dimiliki dan dikelola oleh penerima zakat ${ }^{30}$.

${ }^{28}$ Mubasirun, Distribusi Zakat...hlm 502.

29 Dompet Dhuafa, Pemberdayaan Ekonomi, https://zakat.or.id/program/pemberdayaanekonomi/, akses pada tanggal 22 Januari 2020.

30 BAZNAS, Program Zakat Baznas: https://lpembaznas.com/ Akses 22 Januari 2020 
Program pemberdayaan ekonomi umat di atas merupakan sedikit contoh dari program pemberdayaan yang dilakukan oleh lembaga amil zakat, di setiap lembaga amil zakat yang ada di Indonesia hampir memilki program pemberdayaan ekonomi umat, mereka memiliki tujuan yang sama yaitu mensejahterakan masyarakat. Diharapkan melalui beberapa program zakat ini bisa dijadikan solusi bagi permasalahan ekonomi umat, dikarenakan masih banyak umat Islam di negeri ini yang masih terbelenggu dalam pusaran kemiskinan.

2) Pemberdayaan sumber daya manusia

Pemberdayaan Sumberdaya manusia ini bisa diartikan sebagai ikhtiar guna menyiapkan sumber daya manusia baik itu sebagai perorangan atau sebagai kelompok masyarakat dengan berbagai kedudukannya. Kegiatan pemberdayaan ini bukan hanya terbatas sekedar pembinaan dan sosialisasi saja, akan tetapi tetapi diikuti juga dengan penambahan ketrampilan serta mentalnya sebagai pendukungnya. Program ini diharapkan bisa mempersiapkan sumberdaya manusia yang unggul, serta untuk mempersiapkan seseorang agar mampu berguna bagi bangsa dan agama.

Pengelola zakat di Sleman Yogyakarta mengadakan program "sleman produktif", terdapat 41 mustahik mengikuti pelatihan peningkatan kapasitas yang dilaksanakan oleh BAZNAS kabupaten Sleman. Peserta diikuti oleh takmir masjid, penyuluh agama, serta perwakilan kelompok masyarakat. Kegiatan ini bertujuan untuk menumbuhkan kreatifitas dan motifasi di kalangan mustahik, yang nanti pada tujuan akhir menuju manusia yang unggul. ${ }^{31}$

Selain itu juga untuk meningkatkan kaspasitas amil, beberapa lembaga amil zakat menyelenggarakan kegiatan pelatihan bagi amil zakat dan dananya juga diambilkan dari dana zakat. Misalnnya Pada tanggal Rabu, 31 Juli 2019 BAZNAS Provinsi Jawa barat menyelenggarakan kegiatan pelatihan Sumber Daya Manusia dengan tema Excellent Team Training, Pembentukan Tim Untuk Meningkatkan Kohesivitas. Dalam rangka untuk tercapainya kesuksesan organisasi yakni adanya kerja tim. Pada saat ini lingkungan Sumber Daya Manusia selalu mengalami perubahan baik dari segi nilai, norma, dan teknologi. Untuk itu membutuhkan modal yang kuat untuk menghadapi lingkungan terus berubah. Modal yang terpenting untuk pengelola/amil zakat adalah Self-Developing melalui rangkaian kegiatan pelatihan dan Pengembangan SDM. Diharapkan melalui penelitian ini para amil memiliki bekal yang cukup dan nantinya menjadi pengelola zakat yang professional. ${ }^{32}$

31 Amelia Hapsari, Penerima Zakat Dilatih Peningkatan Kapasitas, https://www.suaramerdeka.com/news/baca/175998/penerima-zakat-dilatih-peningkatankapasitas, Akses 23 januari 2020.

32 Baznas Provinsi Jawa Barat, Pelatihan dan Pengembangan SDM Amil Baznas Jabar, diakses melalui: https:// baznasjabar.org/news/pelatihan-dan-pengembangan-sdm-amil-baznas-jabar, Akses 23 Januari 2020. 
Penjelasan beberapa contoh di atas merupakan program pemberdayaan SDM melalui dana zakat, akan tetapi menurut penilis masih banyak lembaga amil zakat yang belum menyelenggarakan pemberdayaan SDM untuk meningkatkan ketrampilan agar menjadi manusia yang unggul yang mampu berkomptisi di masa depan. Banyak lembaga amil zakat masih focus pada program bantuan zakat konsumtif dan pemberdayaan ekonomi.

Indonesia merupakan negara dengan penduduk muslim terbesar di dunia, dan tentunya memiliki potensi zakat yang cukup besar untuk bisa dikembangkan. Akan tetapi yang terjadi di lapangan potensi zakat yang begitu besar masih belum maksimal penggunaanya. Hal ini ditunjukkan dengan masih banyaknya masyarakat muslim yang belum mandiri dan berdaya serta masih di bawah garis kemiskinan. Meskipun saat ini bermunculan lembaga amil zakat untuk mengelola zakat, akan tetapi belum bisa berdampak secara signifikan dalam membantu membebaskan ummat dari kefakiran dan kemiskinan. Masalah yang paling mendasar bukan hanya semata distribusi zakatnya, selain itu juga kurang maksimalnya dana zakat yang terkumpul dari potensi dana yang ada. Oleh sebab itu lembaga amil zakat perlu mengedukasi kepada masyarakat terutama umat Islam atas perlunya kesadaran kewajiban membayar zakat. Sehingga potensi zakat yang begitu besar tersebut bisa bermanfaat dan bisa mengurangi permasalahan umat dan membantu negara dalam mensejahterakan rakyatnya. Banyaknya lembaga amil zakat dan beberapa programnya yang bermunculan saat ini merupakan hal positif, karena sedikit membantu permasalan masyarakat, dan juga bisa dijadikan "trigger" untuk manajemen dan optimasi potensi zakat yang lebih baik ke depan.

\section{KESIMPULAN}

Potensi zakat di Indonesia memiliki nilai yang cukup besar, hal ini di dasarkan pada jumlah penduduk muslim di Indonesia menempati urutan pertama di Indonesia. Meskipun begitu zakat di Indonesia belum begitu besar perannya untuk memberdayakan masyarakat di Indonesia. Dari berbagai analisis di atas sebenarnya perkembangan manajemen zakat untuk pemberdayaan masyarakat dikelola sejak zaman Islam masuk di negeri ini yaitu pada zaman kesultanan Islam yang tercatatat dalam sejarah, dari mulai kerajaan samudra pasai sampai pada zaman kesultanan mataram di yogyakarta, dilanjutkan dengan pada zaman kolonial belanda, manajemen zakat terus di lakukan oleh umat Islam dengan segala keterbatasannya. Kemudian pada masa kemerdekaanya pemerintah mengeluarkan peraturan tentang zakat, meskipun masih pada tataran zakat fitrah. akan tetapi hal ini bisa dijadikan pondasi awal manajemen zakat untuk lebih professional. Di zaman orde baru manajemen zakat mulai dikelola secara professional, yaitu dengan berdirinya BAZIS, serta disusun regulasi untuk kegiatan zakat, sehingga pengeloaan zakat di Indonesia diakui, difasilitasi, dan dilegalkan oleh negara. Setelah itu pada saat reformasi, UU Nomor 38 Tahun 1999 tentang manajemen zakat diterbitkan, dari sinilah sebagai pijakan manajemen 
zakat saat ini, dan juga diikuti dengan munculnya beberapa lembaga amil zakat. Umat Islam berlomba lomba untuk mengelola dana zakat untuk kemaslahatan umat.

Seiring dengan perkembangnya saat ini manajemen zakat dibagi menjadi 2 yaitu zakat konsumtif dan zakat produktif. Zakat konsumtif adalah, zakat yang dikeluarkan kepada mustahik berupa bantuan tunai berbentuk kebutuhan sehari hari, biaya kesehatan, biaya pendidikan dan biaya keperluan mendesak lainnya. Kedua adalah zakat produktif yaitu pemberian zakat, yang nantinya bisa membuat mustahik mendapatkan hasil secara berkelanjutan dengan dana zakat yang telah diterimanya. Zakat ini bertujuan untuk pemberdayaan umat agar mereka bisa mandiri secara ekonomi dan tidak menganggantungkan hidupnya pada bantuan orang lain itu. Di dalam zakat produktif para lembaga amil zakat berlomba lomba membuat program untuk pemberdayaan masyarakat yang bertujuan mengentaskan umat dari lingkaran kemiskinan, seperti ada program janda berdaya, program lumbung pangan, dan mustahik berdaya. Selain untuk pemberdayaan ekonomi umat zakat produktif ini juga ada program pengembangan sumber daya manusia, di dalam program ini para penerima zakat diberikan pelatihan untuk meningkatkan ketrampilan dan mental dirinya agar menjadi manusia yang unggul dan memiliki kompetensi lebih. Di samping untuk para mustahik, pengembangan sumberdaya manusia ditujukan untuk pengelola zakat (amil) hal ini bertujuan untuk meningkatkan profesionalisme manajemen zakat.

Saat ini manajemen zakat di Indonesia berjalan cukup progresif. Hal ini ditunjukkan dengan banyaknya lembaga amil zakat, serta semangat beragama yang cukup tinggi di kalangan masyarakat kita. Akan tetapi manajemen ini masih berjalan belum maksimal, nilai zakat trilyunan rupiah belum tergali secara maksimal, dan juga banyak masyarakat yang belum memiliki akses ataupun belum mengetahui program lembaga amil zakat yang telah ada, sehingga menurut penulis dana zakat belum dirasakan secara masif oleh masyarakat. Diharapkan kedepan lembaga amil zakat mampu untuk terus mennghimpun, menggali dana zakat agar bisa didistribusikan kepada yang berhak, dan selanjutnya zakat bisa dirasakan manfaatnya secara menyeluruh oleh masyarakat, dan juga membantu negara untuk mensejahtearkan rakyatnya.

\section{DAFTAR RUJUKAN}

Atabik Ahmad, "Manajemen Pengelolaan Zakat Yang Efektif Di Era Kontemporer" Jurnal Ziswaf, Vol. 2, No. 1, 2015.

Amalia, dan Kasyful Mahalli, "Potensi Dan Peranan Zakat Dalam Mengentaskan Kemiskinan di kota Medan", Jurnal Ekonomi dan Keuangan, Vol. 1, No.1, 2012.

Asnaini, “Zakat Produktif dalam Persfektif Hukum Islam”, Yogyakarta: Pustaka Pelajar, 2008.

Azyumardi Azra, "Filantropi dalam Sejarah Islam di Indonesia", Jakarta: Forum Zakat (FOZ), 2006. 
Bahari, Zakaria "Peran Zakat dalam Pendidikan Masyarakat Islam: Ulasan Kasus Zakat Pulau Pinang", Jurnal Media Syariah, Vol. XVI No. 1 Juni 2014.

Baznas Provinsi Jawa Barat, "Pelatihan dan Pengembangan SDM Amil Baznas Jabar", https://baznasjabar.org/news/pelatihan-dan-pengembangan-sdm-amil-baznas-jabar, Akses 23 januari 2020.

Baznas, Program Zakat Baznas diakses melalui: https://lpembaznas.com/, Akses 22 Januari 2020.

C. Van Vollenhoven, Het Adatrecht van Nederlandsch Indie, Jilid. I, Leiden: E.J. Brill, 1931.

Clarashinta Canggih dan Khusnul Fikriyah, Ach. Yasin, "Potensi Dan Realisasi Dana Zakat Indonesia", Jurnal al-udud, Vol. 1, No. 1, 2017.

Depag RI, “Pedoman Zakat”, Jakarta: Badan Proyek Peningkatan Zakat dan Wakaf, 2002.

Dompet Dhuafa, "Optimalisasi Potensi Zakat Di Indonesia", $\underline{\text { http:// }}$ www.dompetdhuafa.org/post/detail/7626/optimalisasi-potensi-zakat-Indonesia. Akses 15 Agustus 2019.

Dompet Dhuafa, "Pemberdayaan Ekonomi", https://zakat.or.id/program/pemberdayaanekonomi/, Akses 22 Januari 2020.

Faisal, "Sejarah Manajemen Zakat Di Dunia Muslim Dan Indonesia (Pendekatan Teori Investigasi-Sejarah Charles Peirce dan Defisit Kebenaran Lieven Boeve" , Jurnal Analisis, Vol. XI, No. 2, 2011.

Fakhruddin, "Fiqh dan Manajemen Zakat di Indonesia", Malang: UIN Malang Press, 2008.

Hafidhuddin, Didin, “Zakat Dalam Perekonomian Modern”, Jakarta: Gema Insani, 2002.

Hasan, Muhammad, Manajemen Zakat: Model Manajemen Zakat yang Efektif, Yogyakarta: Idea Press, 2011.

Hishora Fondation, "Zakat Pendidikan Untuk Anak Indonesia", https://www.hoshizora.org/zakat-untuk-pendidikan-anak-Indonesia/, Akses 21 Januari 2020.

Jambi link, "Bantuan Biaya Hidup Bagi Warga Kurang Mampu Dari Zakat PNS", https://jambilink.com/2019/04/24/bantuan-biaya-hidup-bagi-warga-kurangmampu-dari-zakat-pns/amp, Akses 20 Januari 2020.

Kata data. "Indonesia Negara Berpenduduk Muslim Terbesar Dunia," https://databoks.katadata.co.id/datapublish/2016/11/11/Indonesia-negaraberpenduduk-muslim-terbesar-dunia, Akses 15 Agustus 2019.

Media Indonesia, "Zakat Bisa Dimanfaatkan Warga Miskin Bayar BPJS Kesehatan," https://mediaIndonesia.com/read/detail/269661-zakat-bisa-dimanfaatkan-wargamiskin-bayar-bpjs-kesehatan, Akses 22 Januari 2020.

Mubasirun, Distribusi Zakat Dan Pemberdayaan Ekonomi Umat, Jurnal Inferensi, Vol. 7, No. 2, 2013. 
NU, Hukum Zakat Produktif untuk Pendayagunaan Mustahik, https://Islam.nu.or.id/post/read/46324/hukum-zakat-produktif-untukpendayagunaan-mustahik Akses 22 Januari 2020.

Republika, “21 Korban Tewas Pembagian Zakat di Pasuruan”, https://www.republika.co.id/berita/breaking-news/nasional/08/09/15/3018-21korban-tewas-pembagian-zakat-di-pasuruan, Akses 20 Januari 2020.

Suara Merdeka. "Penerima Zakat Dilatih Peningkatan Kapasitas", https://www.suaramerdeka.com/news/baca/175998/penerima-zakat-dilatihpeningkatan-kapasitas, Akses 23 januari 2020.

Triantini, Zusiana Elly, "Perkembangan Manajemen Zakat Di Indonesia," Jurnal Al-Ahwal, Vol. 3, No. 1, 2010.

Zulkarnain, Iskandar, “Manajemen Dana Zakat Bagi Pelayanan Kesehatan Mustahik (Studi Pada Rumah Sehat Baznas Yogyakarta)", Skripsi, Yogyakarta: Universitas Islam Indonesia, 2018. 